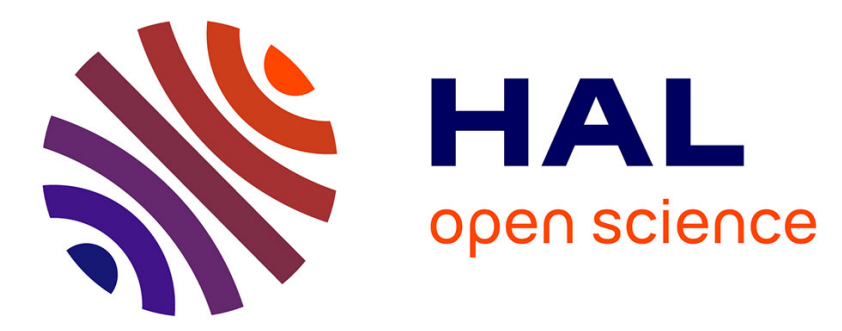

\title{
Financial Statement Analysis for Enterprise Network Design
}

\author{
Luca Cagnazzo, Lorenzo Tiacci, Andrea Cardoni, Massimiliano Brilli
}

\section{To cite this version:}

Luca Cagnazzo, Lorenzo Tiacci, Andrea Cardoni, Massimiliano Brilli. Financial Statement Analysis for Enterprise Network Design. 15th Working Conference on Virtual Enterprises (PROVE), Oct 2014, Amsterdam, Netherlands. pp.295-303, 10.1007/978-3-662-44745-1_29 . hal-01392128

\section{HAL Id: hal-01392128 \\ https://hal.inria.fr/hal-01392128}

Submitted on 4 Nov 2016

HAL is a multi-disciplinary open access archive for the deposit and dissemination of scientific research documents, whether they are published or not. The documents may come from teaching and research institutions in France or abroad, or from public or private research centers.
L'archive ouverte pluridisciplinaire HAL, est destinée au dépôt et à la diffusion de documents scientifiques de niveau recherche, publiés ou non, émanant des établissements d'enseignement et de recherche français ou étrangers, des laboratoires publics ou privés.

\section{(c)(1)}

Distributed under a Creative Commons Attribution| 4.0 International License 


\title{
Financial Statement Analysis for Enterprise Network Design
}

\author{
Luca Cagnazzo $^{1}$, Lorenzo Tiacci ${ }^{1}$, Andrea Cardoni $^{2}$ and Massimiliano Brilli ${ }^{3}$ \\ ${ }^{1}$ Univ. degli Studi di Perugia - Dip. di Ingegneria Via Duranti, 67 - 06125 Perugia - Italy \\ ${ }^{2}$ Univ. degli Studi di Perugia - Dip. di Economia Via Pascoli, 20 - 06123 Perugia - Italy \\ ${ }^{3}$ Netvalue, SpinOff dell’Università di Perugia Via della Pallotta, 13 - 06126 Perugia - Italy
}

\begin{abstract}
Cooperation and collaboration is something already widely discussed in literature and several different types of Enterprise Network Management (ENM) models have been proposed, highlighting a certain degree of maturity of the literature on this topic. Nevertheless, the increasing demand for collaborative forms to face up to the actual market imposes the development of a systematic methodology. The aim of this methodology is to select the most appropriate ENM model for the pool of potential partners, following an engineered process of network design and implementation. In literature, studies on the appropriateness of different analytical frameworks for designing the most suitable ENM model for specific collaborative businesses have been formulated exclusively based on the analysis of non-financial dimensions of the companies; for example the investigated nonfinancial aspects are related to the purpose or the function of the collaboration, to the companies' degree of organization, to the market type or business model, to the pros and cons of the different legal forms, to the soft issues management and to many others. This paper extends the current research and introduces a decisional framework that integrates some of the previous listed endeavors with a quantitative Financial Statement Analysis (FSA) approach in order to guarantee a repeatable, reliable and reproducible selection of the most appropriate ENM model. Finally, the framework is tested in a case study with the aim of validating the methodology.
\end{abstract}

Keywords: Collaborative Network, Financial Statement Analysis, Network Design, Virtual Breeding Environment, Virtual Development Office, T-Holding

\section{Introduction}

Cooperation among companies, especially Small and Medium Enterprises (SMEs), is something already discussed in several works [1]. The benefits coming from the strategic alliances have been studied under different dimensions of analysis, such as economical, financial, strategic, operative; for the opportunities resulting from the collaborations and as a result of the rapidly evolving challenges faced by business entities and society in general, a large variety of business networks have emerged in recent years [2]. Several studies have developed theories and guidelines for the management of the networks in their various stages of life, i.e. the phases of the network creation, the operations, the network evolution/metamorphosis, the network dissolution [3, 4]; thus, these works assume that a certain type of collaboration has already been established [7]. Contrarily, few works have developed tools or frameworks for the selection of the most appropriate 
ENM model for a pool of companies that want to start a collaboration [7] and no papers are available for the selection of the ENM model through a Financial Statement Analysis (FSA) conducted on the potential partners before and during the network creation. Different alliance forms represent different approaches that partner firms adopt to control their dependences on the alliance and on the other partners: the incorrect choice of the collaborative model could lead to the failure of the network. The authors believe that the choice of the most suitable ENM model is determined also by the financial positions of the potential partners of a nascent network. To minimize the risk of the choice of the incorrect ENM model, a FSA of the companies of the future network should be the first activity to be conducted to eliminate incompatible ENM models and to restrict the choice to a few well-matched collaborative forms. This is the objective of the paper, i.e. to present a framework aimed at restricting the choice to one, or two at maximum, ENM models, after an FSA of the companies that want to start a collaboration. The FSA is thus a tool for evaluating the overall financial situation of the potential partners and allows the managers of the nascent network to identify the correct ENM model, according to specific criteria described in the paper. The proposed methodology is, of course, a first attempt to formalize the preliminary phase of the network creation, i.e. the choice of the most suitable management model, and it is one of the criteria for choosing network members, to be used in synergy with other approaches. The paper does not assume that the collaboration has already been established but instead provides a methodology to suggest if an appropriate ENM model exists, or not, and if the companies can somehow collaborate based only on their financial situations. Even if the methodology can be generalized and extended to include other forms of collaborative networks, the authors' analysis considers only three types of collaborative networks and combinations, that are characterized by different degree of business and process integration, taken as representative of long term collaboration forms with different integration degree [12]: the Virtual Development Office (VDO) [5], the Virtual Breeding Environment (VBE) [6] and the Holding and T-Holding organizations [7] (where the T- stands for 'protection', thus a typology of holding suitable for those companies in crisis). The framework has finally been implemented and tested in an industrial case of 4 companies and the most appropriate ENM model is identified and proposed.

\section{Financial Statement Analysis for Enterprise Networks: A Literature Analysis}

Today a wide range of literature is available on the FSA, particularly on its use for forecasting and for taking strategic decisions, for increasing firms' competitiveness or for implementing actions to save companies in crisis, in general for understanding the health of the companies. Nevertheless, the adoption of the FSA for collaborative environments is few documented. This section presents some cases in literature where the FSA has been implemented in environments with growing degrees of collaboration and used as management or forecasting tool. Looking at the FSA for multi-company cases, a first implementation of FSA is presented by [8], that compared the financial performance of two manufacturing companies. The data were gathered from the annual reports of 
companies during the last three years and analyzed by FSA tools, which were financial ratio analysis and comparative financial statement analysis. The findings of the study could help companies to judge their present condition and take decisions about their future steps while taking into consideration financial issues. A broader approach is presented by the study [9] that explored the relationships of supply chain partnership, financial management and enterprise performance. The study used the FSA for assessing

that partnership has significantly and positively influenced financial management; financial management has also significant and positive influence on enterprise performance; from the FSA the authors derived that the supply chain partnership can not only influence enterprise performance directly, but also influence it indirectly through financial management. Very few articles are dedicated to the FSA implemented in collaborative environments. For example, [10] proposes a framework for the FSA of a network of SMEs, employing it as financial measurement of the network. The FSA has been pursued focusing on eight measurement objects that were causally related to form a strategic map. The FSA is illustrated by a case of a leader-driven network of SMEs. Still less papers use FSA for collaborative environment design. [11] introduces a mathematical model that integrates financial considerations with supply chain network design and operation decisions under demand uncertainty. The model is formulated as a MixedInteger Linear Programming problem which incorporates financial statements analysis through financial ratios and, demand uncertainty through scenario analysis and is solved to global optimality using standard branch-and-bound techniques. The applicability of the model is illustrated by using a case study along with a comparison with a non-financially constrained model which supports the superiority of the proposed model and highlights the tradeoffs between these models. There are no papers discussing the use of FSA for designing long-term strategy enterprise networks or using the FSA as a tool for choosing the most appropriate business model for a pool of companies that want to start a reciprocal collaboration. The following paragraphs describe the framework used for this purpose and its implementation in a real industrial case.

\section{The Framework: FSA for Enterprise Network Design}

The framework for Enterprise Network Design (END) through FSA is depicted in Figure 1. It extends the methodology proposed by [7], and it covers the gap consisting in the missing analysis of financial dimensions of the potential partners that want to start a collaboration. The FSA is thus used to measure the economic performance and appraise the financial position of the company. On the basis of the FSA results, the framework suggests, if they exist, one or two more appropriate Enterprise Network Management (ENM) models for the pool of potential partners, and considers three ENM models, taken as representative of long term collaboration forms with different integration degrees [7]: the Virtual Development Office (VDO), the Virtual Breeding Environment (VBE) and the (T-)Holding organizations (including both the Holding and the T-Holding). However, the methodology can be generalized and extended to include other forms of collaborative networks. The procedure represented by the framework is divided in 3 different stages of 
analysis: 1 quantitative (the first stage) and 2 qualitative (second and third stages). The qualitative analysis of the second stage could be implemented as suggested by [12] and [13], or using different approaches aimed at investigating the heterogeneity or homogeneity of the business models of the companies that would start the collaboration (stage 2 of the framework) and to explore the Strategic Objectives (SOs) of the potential partners. The innovative section of the framework lies in the first and third stages, since the framework in Figure 1 extends the researches of [12] and [13] introducing the concept that some ENM models are included or excluded from the analysis according to the reference values of some financial statements related to the involved firms. In particular, the first stage is an FSA for the evaluation of the financial situation of the potential partners. The financial indicators identified by the authors as suitable for the analysis are: the "financial leverage", the "repayment capacity" and the "incidence of financial expenses". These indicators are a part of a bigger set of financial measurements, nevertheless they represent some of the most important measures adopted by "Standard \& Poors" in its rating system. Based on the reference values of these indicators, it is possible to classify the firms depending on a good or bad financial situation. The reference values are derived from the standard parameters that the Italian (but not only) banking systems adopt to assess the attitude of the company to reimbursing its financial debt. Given the complexity of such kind of assessment, the three indicators have to be read in an integrated manner, concluding that the company is in a good or bad situation in regard to at least two of them. Table 1 summarizes the indicators used for the FSA and illustrates the reference values that allow the author to follow the branches of the framework. For example, if the average value of the financial leverage is smaller than the reference value 3 , then the rationale is "firms in a good financial situation". The second phase of the first stage is the calculation of the firms' performance values. The indicators for the analysis are the "total turnover", the "invested capital", the "ROI" and the "ROE". The aim of the second stage is to evaluate the nature of the companies' business models in their quantitative features, i.e. the degree of homogeneity on how organizations create, deliver and capture value. This also implies the degree of homogeneity of the business strategy, that is something that somehow influences the global network strategy. For the second stage and as mentioned above, the authors propose the qualitative approach proposed in [12], through a questionnaire and a software tool. Another methodology can be implemented that could achieve the same results, and this could be the subject of a future research. In the third and last stage of the framework of Figure 1 the indicators of "strategy planning" and of "aggregation" are monitored. With reference to "strategy planning", "Turnover breakdown by segment", "Cost of core processes" and "Cost of support processes" are simulated through a managerial accounting approach. For "aggregation", the statements to be calculated are "Total turnover", "Value added", "Equity", "Net financial position" and "N. of employees" as aggregated values of the network. The conclusions from the framework can be summarized as follows. The VDO management model can be excluded for those firms with a financial situation evaluated as insufficient based on the reference values and it is more appropriate for those companies that have an heterogeneous business model. The VBE management model can be suitable for every combination of the financial statements, since the nature of the strategic objectives of the model are more oriented to Supporting Process Opportunities. The VBE model thus is not excluded a priori before conducting the last stage of the framework. 


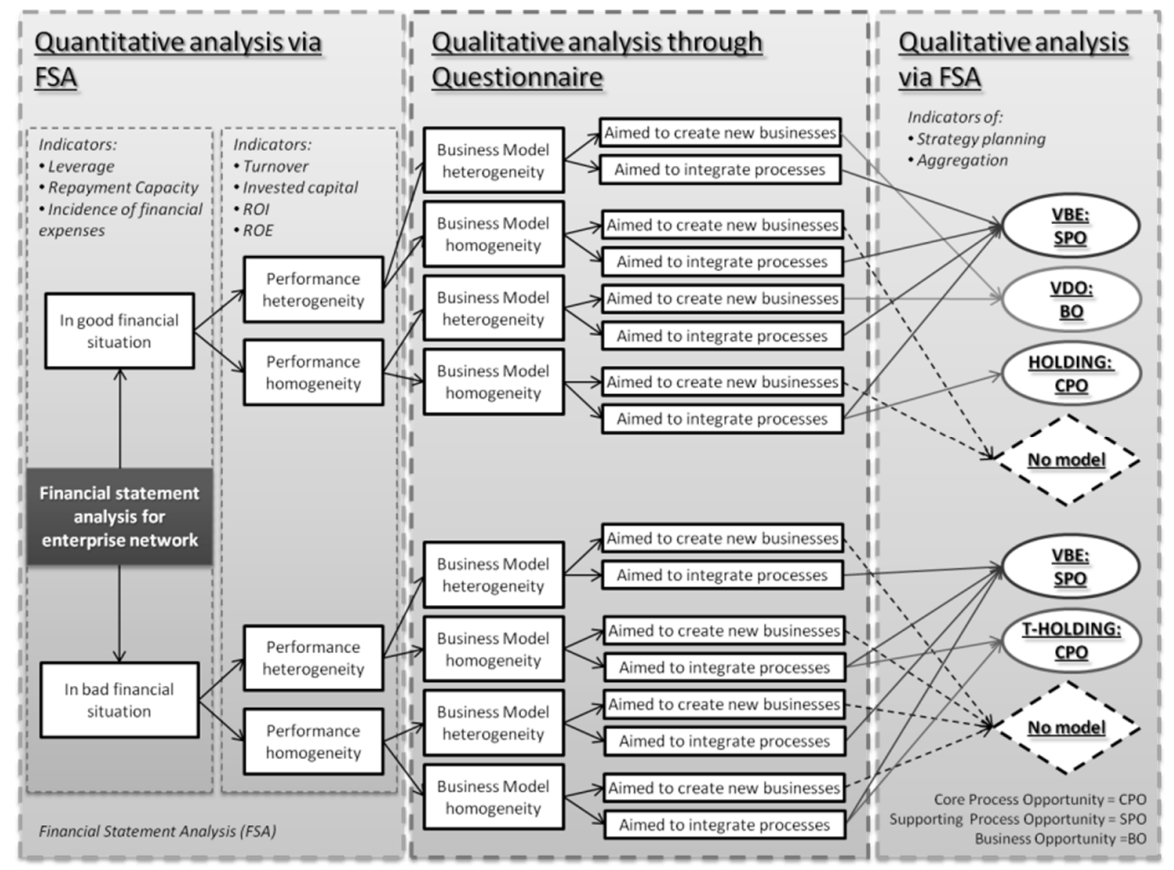

Fig. 1. Framework of analysis

Table 1. Financial Statements Indicators for the analysis and reference values for the rationale.

\begin{tabular}{|c|c|c|c|c|}
\hline $\begin{array}{l}\text { Class of the } \\
\text { indicator }\end{array}$ & Name of the indicator & Calculation & $\begin{array}{c}\text { Ref. } \\
\text { Value } \\
\end{array}$ & Statement/Rationale \\
\hline \multirow{3}{*}{$\begin{array}{l}\text { Financial } \\
\text { situation }\end{array}$} & Leverage & Net financial position/Equity & 3 & If value $<3$ of ref. value: good financial situation \\
\hline & Repayment Capacity & Net financial position/EBITDA & 5 & If value $<5$ of ref. value: good financial situation \\
\hline & $\begin{array}{l}\text { Incidence of financial } \\
\text { expenses }\end{array}$ & Interest expenses/EBITDA & $25 \%$ & If value $<25 \%$ of ref. value: good financial situation \\
\hline \multirow[t]{4}{*}{$\begin{array}{l}\begin{array}{l}\text { Performance } \\
\text { heterogeneity } \\
\text { or homogeneity }\end{array}\end{array}$} & Total Turnover & Income Statement item & $50 \%$ & $\begin{array}{l}\text { If the difference between the average values of the } \\
25 \% \text { the companies' highest turnovers and } 25 \% \text { the } \\
\text { companies' lowest turnovers is }>50 \% \text { of ref. } \\
\text { value: heterogeneity }\end{array}$ \\
\hline & $\begin{array}{l}\text { Invested capital } \\
\text { (IC) }\end{array}$ & Reclassified Balance Sheet & $50 \%$ & $\begin{array}{l}\text { If the difference between the average values of the } \\
25 \% \text { the companies' highest IC and } 25 \% \text { of the } \\
\text { companies' lowest IC is }>50 \% \text { of ref. value: } \\
\text { heterogeneity }\end{array}$ \\
\hline & ROI & EBIT/Invested capital & $5 \%$ & If value $>5 \%$ good operating profitability \\
\hline & ROE & Net Income /Equity & $8 \%$ & If value $>8 \%$ good return on equity \\
\hline \multirow[t]{3}{*}{$\begin{array}{l}\text { Strategy } \\
\text { planning }\end{array}$} & $\begin{array}{l}\text { Turnover breakdown by } \\
\text { segment }\end{array}$ & Management accounting & $\mathrm{n} / \mathrm{a}$ & $\begin{array}{l}\text { Simulate turnover increase of new business } \\
\text { development }\end{array}$ \\
\hline & Cost of core processes & Management accounting & $\mathrm{n} / \mathrm{a}$ & $\begin{array}{l}\text { Simulate cost reduction through core process } \\
\text { integration }\end{array}$ \\
\hline & Cost of support processes & Management accounting & $\mathrm{n} / \mathrm{a}$ & $\begin{array}{l}\text { Simulate cost reduction through support process } \\
\text { integration }\end{array}$ \\
\hline \multirow[t]{5}{*}{ Aggregation } & Total turnover & Income statement item & $\mathrm{n} / \mathrm{a}$ & Calculate total turnover of the network \\
\hline & Value added & Reclassified Income Statement & $\mathrm{n} / \mathrm{a}$ & Calculate total value added of the network \\
\hline & Equity & Balance Sheet item & $\mathrm{n} / \mathrm{a}$ & Calculate total value Equity of the network \\
\hline & Net financial position & Reclassified Balance Sheet & $\mathrm{n} / \mathrm{a}$ & Calculate total Net financial position of the network \\
\hline & N. of employees & Management accounting & $\mathrm{n} / \mathrm{a}$ & Calculate total employees of the network \\
\hline
\end{tabular}

The Holding is suitable for firms in a good financial situation and with high homogeneity in the performance and in the business model. Contrarily the T-Holding is appropriate for companies in bad financial situations and with an homogeneous business model: in fact 
the main mission of the T-Holding is to avoid the collapse and the disappearance of the companies in crisis [7].The "No model" solution could, instead, be proposed for all the bad financial situations and in general for the cases of strong homogeneity in the business model, i.e. where there is a high level of competition among companies or overlapped processes and operations. The aim of this last stage of the framework is to deepen the nature of the network strategy (new businesses or new processes), and to allow the researchers to choose the more suitable ENM model, if it exists and if there is only one. The last stage, whose methodology is presented in [13], has the goal of investigating the nature of the SOs of each considered ENM model, i.e. the reasons why firms aim to start an alliance for a long period, of different sizes and with different integration degrees (Business Opportunities - BOs, Core Process Opportunities - CPOs, Supporting Process Opportunities - SPOs) [12]. The next paragraph presents the implementation of the methodology in an industrial case of 4 companies that wanted to start a collaboration and thus facing the issue of the selection of the most appropriate ENM model

\section{The Case Study}

The Italian company, Elettromil srl, identified the opportunity to collaborate with 3 other companies in a more stable form (in the paper the 4 companies, including Elettromil, are named Company $\mathrm{A}, \mathrm{B}, \mathrm{C}$ and $\mathrm{D}$ in a random order for privacy reasons). The companies were already cooperating in some way with Elettromil, but in the classical suppliercustomer paradigm in a classic supply chain form. The idea of the collaboration had been identified by Elettromil. With a lot of experience in the production of high-voltage transformers, the company perceived an opportunity to proceed to a synergy for the production of specific medium-voltage transformers, enhancing the productive excellence of companies in the territory who were operating in the same sector. The decision to start manufacturing this class of products was made as they are produced, at national level, by a few manufacturers that operate under an oligopolistic market with high margins on raw materials and highly specialized processes. The opportunity was characterized by a growing demand and interest, represented by the renewable energy sector, but also by all the applications on the medium voltage distribution and industrial applications on average voltage. The FSA analysis started from the financial statements summarized in Table 2. Given the overall results of financial indicators, the financial situation has been classified as substantially good and the level of performance heterogeneity as quite strong. From the questionnaire there emerged a moderate heterogeneity of the business model and a strong orientation to create new business opportunities and core process synergies. The final part of the analysis, i.e. the simulation of the turnover increase for new business development, the cost reduction through core process integration and the cost reduction through supporting process integration, suggested that the network strategy was more oriented towards Business Process Opportunities (BPOs). Thus, the VDO can be evaluated as the ENM model. Finally the measurement of the aggregated network values, i.e. total turnover, total value added, total value equity, total net financial position and total employees of the network, suggested that the new integrated entity set-up through a VDO model can be a good solution for facing potential increasing demand. This presents a valuable proposition that benefits from a total turnover of $30.148 \mathrm{~K} €$, a valued added 
incidence on turnover of $18.8 \%$, a total number of employees of 101 and a net financial position of $3.567 \mathrm{~K} €$. The non-collaboration form could imply a weaker strategic position for all the involved companies. Instead, a VDO solution can be an opportunity for improving by taking advantage of the other companies' competences, skills, technologies, etc.: the objective is potentially achievable, and the VDO is the best type of collaborative form to achieve this objective.

Table 2. Financial statements from the case study (values in .000€).

\begin{tabular}{|c|c|c|c|c|c|c|c|}
\hline $\begin{array}{c}\text { Class of the } \\
\text { indicator }\end{array}$ & Name of the indicator & Company A & $\begin{array}{c}\text { Company } \\
\text { B }\end{array}$ & Company C & Company D & Average values & Statement \\
\hline \multirow{4}{*}{$\begin{array}{c}\text { Financial } \\
\text { situation }\end{array}$} & Year & 2012 & 2012 & 2012 & 2012 & 2012 & \\
\hline & Leverage & 1,23 & 16,40 & 62,36 & 0,47 & 19,88 & \multirow{3}{*}{$\begin{array}{l}\text { good financial } \\
\text { situation }\end{array}$} \\
\hline & \multirow{2}{*}{$\begin{array}{l}\text { Repayment Capacity } \\
\text { Incidence of financial } \\
\text { expenses }\end{array}$} & 2,33 & 13,29 & 5,16 & 4,07 & 4,18 & \\
\hline & & $8,21 \%$ & $39,77 \%$ & $26,52 \%$ & $1,83 \%$ & $18,17 \%$ & \\
\hline \multirow{4}{*}{$\begin{array}{l}\text { Performance } \\
\text { heterogeneity }\end{array}$} & Total Turnover & $23.913,64$ & $2.596,69$ & $2.222,63$ & $1.415,21$ & difference $>50 \%$ & \multirow{4}{*}{$\begin{array}{l}\text { heterogeneity in } \\
\text { performances }\end{array}$} \\
\hline & Invested capital & $3.714,79$ & $1.124,93$ & $1.528,57$ & $2.354,68$ & difference $>50 \%$ & \\
\hline & ROI & $17,31 \%$ & $4,12 \%$ & $6,13 \%$ & $3,60 \%$ & $7,68 \%$ & \\
\hline & ROE & $20,58 \%$ & $0,56 \%$ & $26,31 \%$ & $20,13 \%$ & $16,90 \%$ & \\
\hline \multirow{2}{*}{$\begin{array}{c}\text { Network } \\
\text { aggregated } \\
\text { values }\end{array}$} & Total turnover & \multicolumn{2}{|c|}{ Total value added } & \multicolumn{2}{|c|}{ Total Value equity } & $\begin{array}{c}\text { Total net } \\
\text { financial position }\end{array}$ & $\begin{array}{c}\text { Total } \\
\text { employees }\end{array}$ \\
\hline & 30.148 & \multicolumn{2}{|c|}{5.669} & \multicolumn{2}{|c|}{3.567} & 6.099 & 101 \\
\hline
\end{tabular}

\section{Conclusions and Further Research}

Collaboration within a stable long-term strategy enterprise network is nowadays one of the most successful solutions for facing the financial and market crisis; several collaborative networked organization management models are currently formalized in literature and tested successfully in industrial cases studies. Nonetheless, the selection of the Enterprise Network Management model is still something not completely analyzed and it is too much often a casual process, sometimes left to the entrepreneurs' ability to involve partners. Instead, the choice of the most appropriate model should be made not only for achieving the goals of the network strategies, but also on the basis of the financial statements of the companies, in order to guarantee the sustainability of the collaborative environment. Thus, the paper presents a framework for assessing the financial statements of the potential partners, before they start the collaboration, in order to identify, if it exists, the most suitable Enterprise Network Management model among the three referenced models: the Virtual Development Office (VDO), the Virtual Breeding Environment (VBE) and the (T-)Holding. The framework has then been implemented in an industrial context where the VDO has been selected as the most apt management model. The proposed methodology is an initial attempt to formalize the first phase of the network creation, i.e. the choice of the most suitable management model, and it is one of the criteria for choosing network members. Simply having financial compatibility does not mean the potential members have the competencies required. In fact, it is important to highlight that the approach proposed by the authors is first a decisional support and it should be used in synergy with other methodologies: it could be limiting to evaluate the network's potential based on the network's average financial situation. This could contain the risk that the very good financial situation of one partner whitewashes the bad financial condition of another partner, which can result in a critical business situation. For this reason, the approach 
suggested by the authors could be extended considering different financial statements as well as including more alternative scenarios in the framework for covering other possible financial statements of the companies. Finally, for validating purposes, it should also be implemented in other case studies and in different sectors.

Acknowledgments. A special acknowledgement to Elettromil srl that strictly cooperated with the authors to achieve the goal of creating the collaborative network with the other partners.

\section{References}

1. Taticchi, P., Cagnazzo, L., Beach, R. and Barber K.: A management framework for organisational networks: a case study", Journal of Manufacturing Technology Management, Vol. 23 Iss: 5 pp. 593 - 614 (2012).

2. Taticchi, P., Botarelli, M., Cagnazzo, L. (2008). "The virtual development office framework in enterprises network organization: the GPT case study". In conference: POM, Tokyo.

3. Camarinha-Matos, L. M.; Afsarmanesh, H. - Collaborative networks: A new scientific discipline, J. Intelligent Manufacturing, vol. 16, $\mathrm{N}^{\circ} 4-5$, pp439-452 (2005).

4. Cardoni, A., Tiacci, L. (2013): The "enterprises' network agreement": The Italian way to stimulate reindustrialization for entrepreneurial and economic development of SMEs. In: Camarinha-Matos, L.M., Scherer, R.J. (eds.) PRO-VE 2013. IFIP AICT, vol. 408, pp. 471-480. Springer, Heidelberg.

5. Saetta, S., Tiacci, L., Cagnazzo, L. (2013): The innovative model of the Virtual Development Office for collaborative networked enterprises: the GPT network case study. Int J Comput Integ M 26, 41-54.

6. Camarinha-Matos, L.M., Afsarmanesh, H., Galeano, N., Molina, A., (2009). Collaborative networked organizations - Concepts and practice in manufacturing enterprises. Computers \& Industrial Engineering, 57, 46-60.

7. Cardoni, A., Saetta, S., Tiacci, L. (2010): Evaluating how potential pool of Partners can join together in different types of Long Term Collaborative Networked Organizations, 11th Working Conference on Virtual Enterprises, PRO-VE 2010, St.Etienne, Springer, 312-321.

8. Malek, A., Mohammadi, M., Nasiri, F. (2012), "Comparison of Malaysia manufacturing companies by financial statement analysis tools", In Proceedings of: International Conference of Educational Performance and Development, Volume: 1.

9. Zhuang-kuo L. and Shu-bin, Z. (2010), "Empirical Study on Relationship of Supply Chain Partnership, Financial Management and Enterprise Performance", In Proceedings of International Conference on EProduct E-Service and E-Entertainment (ICEEE).

10. Laitinen, E. K. (2006), "Financial statement analysis of a network of SMEs: towards measurement of network performance". International Journal of Networking and Virtual Organizations, Vol. 3, N. 3.

11. Longinidis, P., Georgiadis, M. C. and Tsiakis, P. (2011), "Integration of financial statement analysis in the optimal design and operation of supply chain networks", Computer Aided Chemical Engineering. Volume 29, 2011, Pages 1010-1014.

12. Tiacci, L., Cardoni, A. (2011), "How to Move from Traditional to Innovative Models of Networked Organizations: A Methodology and a Case Study in the Metal-mechanic Industry", In Proceedings of: Adaptation and Value Creating Collaborative Networks - 12th IFIP WG 5.5 Working Conference on Virtual Enterprises, PRO-VE 2011.

13. Tiacci, L. and Cardoni L. (2012), A Genetic Algorithm approach for Collaborative Networked Organizations Partners Selection, In Proceedings of: 13th IFIP WG 5.5 Working Conference on Virtual Enterprises, PROVE 2012 - IFIP Advances in Information and Communication Technology, At Bournemouth; United Kingdom; 1 October 2012, Volume: Volume 380 AICT, 2012, Pages 503-512. 